\title{
Communication in the vehicle cluster of intelligent transport systems
}

\author{
S C RAJKUMAR ${ }^{1}$
}

${ }^{1}$ Affiliation not available

May 24, 2021

\section{Hosted file}

Intelligent Transportation System cluster vehicle communication.pdf available at https: //authorea.com/users/415030/articles/522940-communication-in-the-vehicle-cluster-ofintelligent-transport-systems 